\title{
ENCOURAGING STUDENTS TO HAVE POSITIVE ATTITUDES TOWARD LEARNING ENGLISH
}

\author{
Abdullah Syukur \\ abdullahsyukur@uncp.ac.id \\ Universitas Cokroaminoto Palopo
}

\begin{abstract}
A positive attitude is a powerful tool that fosters enthusiasm, promotes self-esteem, and creates an atmosphere conducive to learning. Achievement in a target language relies not only on intellectual capacity, but also on the learner's attitudes towards language learning. Attitudes could be viewed as a tendency to respond positively or negatively towards a certain thing, idea, person, situation etc. The attitudes that the students should have are attitude towards the language, attitude towards learning the language, attitude towards the language teacher, and attitude towards school in general. This study focuses on discussing about encouraging students to have positive attitudes toward learning English.
\end{abstract}

Keyword: positive attitudes, English, and learning.

\begin{abstract}
Abstrak
Sikap yang positif adalah adalah hal utama yang membantu pengembangan antusiasme, peningkatan kepercayaan diri, dan menciptakan atmosfir yang kondusif dalam pembelajaran. Prestasi pada target bahasa dipercaya tidak hanya kapasitas intelekyual tetapi juga melalui sikap dalam pembelajaran bahasa. Sikap dapat dilihat sebagai sebuah kecenderungan untuk merespon secara positif dan secara negative melalui hal pasti, ide, orang, situasi, dll. Sikap yang seharusnya dimiliki oleh peserta didik adalah sikap terhadap bahasa, pembelajaran bahasa, guru, dan sekolah secara umum. Penelitian ini fokus tentang mendorong peserta didik untuk memiliki sikap positif terhadap pembelajaran bahasa Inggris.
\end{abstract}

Kata kunci: sikap positif, Bahasa Inggris, pembelajaran.

\section{Introduction}

In foreign Language learning context, there are various factors that influence the learning process such as motivation, attitudes, anxiety, learning achievements, aptitudes, intelligence, age, personalities, etc. The matter of learner's attitude is acknowledged as one of the most important factors that impact on learning language. So, developing students' attitudes towards learning is considered to be one of the most important issues that should be taken into account while 
discussing factors affecting the teaching-learning process. Attitudes are a condition for, and a result of, effective instruction; therefore, studies were conducted in various educational fields to examine strategies and techniques that could contribute to developing students' attitudes towards learning. This paper deals with the concept of attitude as one of the major affective factors for success in learning English. It will be explained about definition of attitudes, its components and function, and common attitudes towards learning English.

\section{Discussion}

\section{Definition of Attitude}

There will be some definitions of attitudes in this part based on some experts. Attitudes actually are internal states that influence what the learners likely to do. The internal state is some degree of positive / negative or favorable / unfavorable reaction towards an object. Teachers, learners and researchers will all agree that a high motivation and a positive attitude towards a second language and its community help second language learning. Attitudes towards a particular language might be either positive or negative. Language attitude is an important concept because it plays a key role in language learning and teaching.

Brown (2000) uses the term 'attitudes' to refer to the set of beliefs that the learner holds towards members of the target language group and also towards his own culture. Wenden (1991) suggested a broader definition of the concept "attitudes". He says that the term attitude contains three components namely, cognitive, affective and behavioural. A cognitive component is made up of the beliefs and ideas or opinions about the object of the attitude. The affective one refers to the feeling and emotions that one has towards an object, 'likes' or 'dislikes', 'with' or 'against'. Finally, the behavioural component refers to one's consisting actions or behavioural intentions towards the object.

According to Allman (2000), a successful learner is the one who possess positive attitudes towards the target language. Attitude has been defined by Allportin Chalak (2010) as a mental or neural state of readiness, shaped through experience or dynamic influence on the response provided by an individual to situations and objects. Rasti (2009) defined attitudes towards the subject as the extent to which students accept the subject as well as their opinions towards it. The 
Longman Dictionary of Contemporary English (2001) defined attitudes as "opinions and feelings that you usually have about something".

Thus, Attitudes could be viewed as a tendency to respond positively or negatively towards a certain thing, idea, person, situation etc. Attitudes could highly influence how individuals approach many situations in life, including foreign language learning. It is believed that individuals with positive attitudes usually progress more rapidly in foreign language learning. Attitudes are closely related to our beliefs and are based upon experiences. So that, the writer believes that effective language teaching strategies can encourage students to be more positive towards the learning process in general and learning EFL in particular.

\section{Components and Functions of Attitude}

Components of attitudes:

1. The affective component: feelings about the attitude object.

2. The behavioural component: predisposition to act towards the attitude object in a certain way.

3. The cognitive component: beliefs about the attitude object.

Functions of attitudes:

1. Value-expressive function: enables us to express who we are and what we believe in.

2. Ego-defensive function: enables us to project internally-held conflicts onto others.

3. Knowledge function: enables us to know the world.

4. Utilitarian function: enables us to gain rewards and avoid punishment.

\section{Common Attitudes towards Learning English as a Foreign Language}

Attitude towards the language

First and foremost, what is English language to students? How would the language affect students' life? Would students ever use the language? These questions and many more will determine the level of enjoyment, learning, and benefit one will acquire. The right attitude, once we have the right attitude, then everything else will fall in place. Learning will be easy, lessons will be enjoyed, and in the end we have a lot to benefit from the language. Other people cannot give 
us the attitude needed. It comes from within us. We need to look at the language positively. For Instance, it's important to know the language; it feels good to be able to use the language.

\section{Attitude towards learning the language}

To have a positive attitude towards the language is a good start to learn the language. The whole learning process would be much easier. We would not be shy to make mistakes as we understand that making mistakes is a part of the learning process. We would also be able to accept being laughed at, corrected by others, and other negative responses that might arise from people around us as a result of using the language.

The most important thing here is the urge to learn the language. Once we have this urge, we would be willing to go through it all. Sometimes, this urge might come initially by being forced into learning the language. Or, the urge might grow out of happenings and occurrences in life.

\section{Attitude towards the language teacher}

The most important thing here is having respect and no ill feelings towards the language teacher. If he dislikes or disrespects the teacher, how would he go through the periods when the teacher is teaching? There are several alternatives. One, He can ignore the teaching. Two, He can pretend that he is listening but actually doing something else. Three, He can put down his head on the table and doze off. Four, He can create a fiesta in the class. Or, He can do a disappearing act. Whatever it is that he does, it will just be a waste of time; not so much of the teacher's, but definitely a whole lot of his.

As far as the language teacher is concerned, he is around with one objective in mind. To teach the language however he could. How he delivers the knowledge, depends on his style of teaching. Every teacher is different and therefore has his own style of teaching. The approach that the teacher uses depends largely on his audience. There is no one best style or approach. We have to accept the fact that teachers are not superpowers. We are all human. Our mood changes according to the environment. Nevertheless, whatever is done in the classroom, it is done with good intentions. That is, at the end of the day, students should have learnt one or two language skills, if everything goes well. No teacher in the world can force 
students to learn the skills. Good teachers do not force knowledge onto their students. They impart it to the learners. There is so much that can be done by the teacher, but at the end of the day, it is all up to the students whether or not to participate positively in the lesson. In other words it all boils down to our attitude. So, it is all about eexternal force versus internal desire.

So here, it is crucial that students play their role. The role they play depends very much on their attitude towards the language itself and learning it. For instance, if students perceive the English language as not important, learning the language is a sheer waste of time. Whatever the work they produce is done out of routine, i.e. to complete the work given by the teacher. In this case, students will not learn much, worse still, if students refuse to do the tasks given. Of course students will be bored to death.

\section{Attitude towards school in general}

Reasons for schooling:

Before students begin any lesson at school, there should be some questions answered. Why do they come to school? Is it because their parents send them there every morning? Or, do they come to school to be with their friends? Or, being at school is better than at home listening to their mum's nagging? Or, they simply want to learn? Only students know why they go to school. No matter what the students' reasons are, the teacher is ever ready to impart knowledge because that is his only reason for being at school, a place to give and impart formal education. Students' level of responsibility: Once they know the reason why they go to school, then they should know their responsibilities as a student. Among others, do the tasks given, take part in class activities, complete the homework, take initiative to do extra work in addition to the ones given, and last but not least, respect the teacher.

\section{Attitudes toward Language, Language Learning, and Language Tests}

Students may wish to learn a foreign language because of its practical benefits, like finding a job, or they might learn it to become similar to native speakers, or at least talk to them or travel to their country. Holmes (1992) believes that people develop attitudes towards languages which reflect their views about those who speak the languages, and the contexts and functions with which they are associated. Attitudes in the context of language learning are defined as the way 
people look at the language, the class and the people, and the culture of language. According to Brown (2000), second language learners benefit from positive attitudes and negative attitudes may lead to decreased motivation. Nevertheless, he believes negative attitudes can be changed, often by exposure to reality - for example, by encounters with actual persons from other cultures. Positive attitudes on the part of language learners can cause the development of an integrative motivation and this can consequently facilitate second language achievement. The influence of initial motivation and attitudes upon success in language learning is widely acknowledged. Holmes (1992) state that if people feel positive toward those who use the language, they would be more successful and also more highly motivated toward learning it.

Melhim (2009) examined the language and culture attitudes of middle school students participating in a foreign language exploratory program. Results clearly revealed that many students enter their first language class with misconceptions about language learning that may hinder their progress or persistence in language study. If second language learners initiate their language learning while they have negative attitudes towards the target language and the people using that language, they are not expected to make considerable progress in their process of language learning. Paran (2009) found in a study regarding attitude of language learners that students' beliefs and attitudes about language learning may vary based on cultural background and previous experiences. Thus, it can be argued that positive or negative attitudes do not develop accidentally but have some reasons for their emergence.

Hence, it can be argued that having positive or negative attitudes towards a certain language can exert considerable effect on the learners' performance on a language test. By the same token, learners' attitudes towards a certain language proficiency test may affect their performance on that test.

\section{Build Students' Positive Attitudes}

A positive attitude is a powerful tool that fosters enthusiasm, promotes selfesteem, and creates an atmosphere conducive to learning. If the students do not believe in themselves and their abilities, it is important to change that belief for 
learning to take place. We can nurture a positive learning attitude by verbalizing positive expectations and by expressing praise for jobs done well and on time.

According to Allman et al. in a book Skills for Successful Teaching, there are some tips for building positive attitudes, they are:

1. Look for opportunities to praise your students' efforts. Even a little recognition, as long as it is genuine, goes a long way. Tip: Avoid hollow praise-save words like "terrific" for truly outstanding accomplishments. Use a smile, a light touch on the shoulder, or a wink to recognize everyday efforts.

2. Encourage your students to look upon their educations as their "jobs." But rather than working for someone else, they are working for themselves. Explain that they are building the foundation for their futures - each thing they learn is like a brick laid for a future skyscraper! What they do now can help them stand tall and strong throughout their lives.

3. Encourage your students to develop an interest in what they are learning. Interest is a great aid to learning. Explain that the more they learn about a subject the more their interest will increase.

4. Give your students positive reinforcement for desired behavior and attitudes.

5. Set up a reward system for accomplishing short- and long-term goals. When used properly, rewards can be an effective way to bring about desired study habits.

6. Let your students see how you organize yourself. Show them your lesson plans, your daily schedule, and other organizational tools you use. Ask them to speculate about what a school day would be like if there were no set plans for what to do and when.

7. Make the tips you present on organization, time management, and study habits meaningful and relevant to your students. Example: As you give an in-class assignment, ask the students to estimate how long they think you should allow for completing it and why. Tell them how you estimate the time an assignment or other activity could take and how you rely on these skills daily.

8. Show your students how you schedule your time and activities. Stress the importance of organizing one's time. 
9. Point out to your students that everyone is required to do tasks of which they are not particularly fond. Talk to them about some of the things you must do and how you motivate yourself to tackle them.

10. Encourage your students to use "mind-motivators"- thoughts that get them mentally moving. Have them think about activities they must force themselves to do, such as homework or piano practice. Tell students to motivate themselves by applying "mind talk" to do these things. Example: "If I start this now, I'll be done before dinner, and still have time to go out and play!"

11. Impress upon your students that they are in control of what they do. Tell them to visualize being the driver on the "bus of life," not a passenger.

\section{Conclusion}

An attitude is a rather permanent way of thinking, feeling and behaving toward something or someone. Attitudes could be viewed as a tendency to respond positively or negatively towards a certain thing, idea, person, situation etc. Achievement in a target language relies not only on intellectual capacity, but also on the learner's attitudes towards language learning. This means that learning language should be approached primarily as a social and psychological phenomenon rather than as a purely academic one. So we have been concluded that the ability of the students to master a second language is not only influenced by the mental competence or, language skills, but also on the students' attitudes towards the target language. The attitudes that the students should have are attitude towards the language, attitude towards learning the language, attitude towards the language teacher, and attitude towards school in general.

\section{References}

Allman, B. (2000). Skills for Successful Teaching. USA. McGraw-Hill Children's Publishing.

Brown, D. H. (2000). Principle of Language Learning and Teaching4th Edition. New York: Longman.

Chalak, A. (2010). Motivation and Attitudes of Iranian Undergraduate EFL Students towards Learning English. Journal of Language Studies. Khorasgan Branch (IAUKB) Islamic Azad University Iran. 
Holmes, J. (1992). An Introduction to Sociolinguistics, Attitudes and Applications. London and New York: Longman.

Melhim, A. \& Rahman, A. (2009). Attitudes of Jordanian College Students towards Learning English as a Foreign Language. Jordan: Project Innovation (Alabama).

Paran, G. \& Tibli, P. (2009). Perceived Parental Encouragement, Motivation, and Attitudes towards Learning English Language among Tertiary Students. Proceedings of the 2nd International Conference of Teaching and Learning (ICTL 2009). INTI College. Malaysia.

Rasti, I. (2009). Candidates' Attitudes towards IELTS. The Asian EFL Journal Quarterly, 11(3).

Saleh, S. K. (2012). Group Work and Attitudes of Non-English Major Students towards Leaning EFL. International Journal of Humanities and Social Science. The World Islamic Sciences and Education University (W.I.S.E.). Amman. Jordan.

Tahaineh, Y. \& Daana, H. (2012). Jordanian Undergraduates' Motivations and Attitudes towards Learning English in EFL Context. International Review of Social Sciences and Humanities. Department of English Language and Literature. Princess Alia University College Al-Balqa' Applied University. Amman. Jordan.

Wenden, A. L. (1991). Learner Strategies in Language Learning. Englewood Cliffs, NJ: Prentince Hall. 